\title{
Capital Flight and Domestic Investment in Nigeria: Evidence From ARDL Methodology
}

\author{
Lionel Effiom ${ }^{1}$ Alfa Charles Achu ${ }^{1} \&$ Samuel Etim Edet ${ }^{2}$ \\ ${ }^{1}$ Department of Economics, University of Calabar, Calabar, Nigeria \\ ${ }^{2}$ Department of Business Management, University of Calabar, Nigeria \\ Correspondence: Lionel Effiom, Department of Economics, University of Calabar, Calabar, Nigeria.
}

Received: October 11, 2019

Accepted: November 14, 2019

Online Published: November 26, 2019

doi:10.5430/ijfr.v11n1p348

URL: https://doi.org/10.5430/ijfr.v11n1p348

\begin{abstract}
Capital flight is a challenge for many developing countries of the world. The problem is more severe in a nation like Nigeria where domestic investment has been terribly affected. This study undertakes an empirical investigation of the impact of capital flight on domestic investment in Nigeria between 1980 and 2017. Deploying the Auto Regressive Distributed Lag (ARDL) econometric methodology, the study finds that capital flight has negative and significant impact on domestic investment. In particular, the long run impact of capital flight on domestic investment (0.57) turns out to be more severe than its impact in the short run (0.27), implying that a continuous and persistent build-up of capital flight exerts a negative cumulative effect on domestic investment over time. The study further reveals that the quality of institutions in Nigeria is a disincentive to domestic investment. It therefore recommends the strengthening of institutions to rein in on the illegal outflow of capital from the Nigerian economy in order to guarantee the availability of investible funds. The real sector of the local economy must be grown to bolster the value of the naira. This will stem the tide of capital flight and attract investments into critical sectors.
\end{abstract}

Keywords: capital flight, domestic investment, auto regressive distributed lag model

JEL Classification: E 22, F32

\section{Introduction}

Critical to the development of economies all over the world is domestic investment, conceptualised to be additions to the capital stock. The magnitude of capital stock in an economy is important in promoting productivity that would in turn boost economic development in the long term. Investment leads to the process of capital formation and enhances the productive capacity of an economy. Hence, neoclassical economic theory underlines the role of savings and general resource mobilization as a crucial process in generating investment for each cycle of production. The acquisition of capital-producing as well as income-generating assets within the domestic economy, rather than abroad is a way this can be done. Savings plays a significant role, because countries that have a higher propensity to save have more accumulated income (World Bank, 2007). The more a country can save, the greater its financial resource base which could be channelled into investments that will increase the capital stock and lead to higher levels of productivity. Thus, increasing the savings potential of the economy is a critical imperative of macroeconomic policy. Theory suggests several measures in achieving this, namely, decreasing the incremental capital-output ratio (ICOR) in the aggregate production function as well as curbing capital flight.

Capital flight is seen as the outflow of financial resources in the form of massive transfer of currency from one country to another. Capital flight comprises all illegal flows structured to disappear from the records in the country of origin, and earnings on the stock of illegitimate capital movement outside of a country that generally do not return to the country of origin (Englama, Oputa, Ogunleye and Omotosho, 2007). Economic agents take their capital away from domestic economies to avoid extremely high losses on their domestic assets when economic fundamentals are deemed not right for investment within the domestic economy. Theory suggests that investors will move their capital away from countries with high sovereign risk and uncertainty so as not to make losses from investing in uncertain economic climates. This is the case of Nigeria and most developing economies (Englama $e t$ $a l$, 2007). Indeed, the prevalence of capital flight is more worrisome for Nigeria given that the economy relies significantly on foreign direct investment (FDI) relative to domestic investment. On top of the list of highest FDI 
recipients in Sub-Saharan Africa is Nigeria, raking in an estimated 10 to 15 percent of aggregate FDI flowing into the sub-continent (FDI Financial Intelligence, 2014; Effiom \& Ebi, 2016). Since 1995, FDI as a ratio of Nigeria's GDP has consistently been on the rise, peaking at 24.4 percent in 2017 (UNCTAD, 2018). And this impressive record is apparently compromised by the rising wave of flight capital out of the economy.

The magnitude of capital flight from Nigeria in the recent past has been alarming when compared to accumulated domestic investment within the same period. And this leads to a decline in potential economic growth. For example, dollar estimates of Nigeria's capital flight in 2010 stood at $\$ 311,431.3$ million, representing about $158.2 \%$ capital flight to GDP ratio. Indeed, Deppler and Williamson (1987) lament that economic growth in Nigeria is significantly retarded by an amount equal to the magnitude of the capital flight from the country. Current studies corroborate this assertion (Lawanson, 2008; Adetiloye, 2012).

The Nigerian economy is facing huge financial losses as politicians, corporate bodies and foreign investors are moving funds massively out of the country. In a survey of payments made by the Central Bank of Nigeria (CBN) on behalf of the public, a total of $\$ 22.1$ billion went out of the country in five weeks, at an average of $\$ 4.5$ billion a week. While about $\$ 3.083$ billion went out in the week ending $31^{\text {st }}$ July 2014 , the amount of foreign exchange flowing out of the country rose to $\$ 5.35$ billion for the week ending November $30^{\text {th }}, 2014$ (CBN Statistical Bulletin 2014). Capital flight has been said to be a leading cause of the crash of the naira exchange rate which had remained stable before the elections of 2015. Though the CBN has attributed the collapse of the naira to currency speculators who buy and hold currency to sell at a future date at a higher rate to make gain, the movement of funds out of the country comes by way of Nigerian residents buying up dollars with their naira and moving it offshore.

Capital flight has also been said to have led to the depletion of Nigeria's foreign reserves, thus weakening the naira. Nigeria's foreign exchange reserves, which stood at $\$ 5.4$ billion in 1999 , rose to an overwhelming level of $\$ 51.3$ billion at the end of 2007 and further to $\$ 53.0$ billion in 2008 . However, the crash in the international price of crude oil in 2008 and the aftermath of the global financial crisis ensured that the reserves declined to $\$ 42.4$ billion in 2009, declining further from $\$ 38.138$ billion at the end of April 2014 to $\$ 33.04$ billion in February 2015 (World Bank, 2015).

Ndikumana (2000) observed that Nigeria is among many African economies that have achieved significantly lower investment levels as a result of capital flight. World Development Indicators (2015) recorded that $\$ 43.8$ billion was the domestic investment in Nigeria for the year 1990. This figure dropped to $\$ 37.3$ billion in 1992, declining further to $\$ 20.1$ billion in 1995 . Between 2010 and 2015, the nation recorded a massive outflow of capital in total of over $\$ 900$ billion compared to a relatively low level of domestic investment in total of about $\$ 134$ billion. With such investment levels, one can only but wonder about the multiplier effects on other aspects of the economy, like the rate of unemployment as well as income distribution.

Several studies have been undertaken on capital flight in Nigeria, mostly focusing on its effect on economic growth (Onwioduokit, 2000; Umoru 2013, Ajayi, 1995; Samson and Edeme, 2012, etc.). The present study departs from previous ones in that it focuses on the domestic investment effects of capital flight. We note that Adetiloye (2012) purported to investigate the effect of capital flight on investment in Nigeria. But a careful reading of that study reveals a fundamental flaw in the model specification. The capital flight variable was patently missing in the empirical model, thus calling into question the validity of the conclusions and recommendations proposed in that paper. A similar study was done by Adesoye, Maku, and Atanda (2012) who found a positive and insignificant relationship between capital flight and investment. This curious result, much contrary to theory, was not surprising as the study itself claimed that the estimated model was unstable. Our present effort aims at correcting these flaws and employing a different empirical methodology in investigating the effect of capital flight on investment in Nigeria. Secondly, this study goes a step further by employing data on domestic investment that incorporates both investments at the federal and sub-national units. This is because Nigeria is a federation consisting of the Federal government and the component 36 states and the Federal Capital Territory, Abuja, and the combined investment profile of these federating units adds significantly to that of the federal government to alter the level of national income, output and employment in the long run. However, in most empirical works, there is so much attention paid to fiscal activities at the Federal level to the neglect of same by the combined activities of the component units. Finally, the study finds relevance and resonates with the policy focus of the Nigerian government as it battles institutional graft in government operations. The Abacha loot, which is still being repatriated from safe havens in Western countries decades after the death of the former Nigerian dictator is a stark reminder of the depths in which capital flight had assumed in Nigeria.

The rest of the paper proceeds as follows. The next section reviews the extant and related literature and theories of capital flight. It also explores the stylised facts on capital flight and domestic investment in Nigeria. The 
methodology is discussed in section 3, while the empirical results are presented and discussed in section 4 . The study concludes with section 5 with some policy recommendations.

\section{Literature Review}

\subsection{Conceptual Issues}

In the Keynesian tradition, investment is conceptualised as additions to the capital stock, which results in increases in the level of output and income. These additions to capital are funded through domestic savings and/or foreign aid. Heim (2008) views investment as the acquisition of goods that are not consumed immediately but are used to create further capital. The creation of further capital aids in generating income within the domestic economy. Investments made by the numerous units in the economy are either from domestic sources or foreign sources.

Domestic investment thus is the total quantity of capital acquisition made in an economy at any given time, which most times come from aggregated domestic savings. Domestic investment can be divided into private domestic investment and public domestic investment. Public domestic investments are made by the government in order to increase employment, stabilize prices and boost economic growth, and they are most effectively captured by expenditure on capital projects. Private domestic investments are made by business entities and private sector investors towards large scale business expansions that will benefit the domestic economy. Private domestic investment can be captured by gross fixed capital formation. Domestic investment can be said to be equivalent to gross fixed capital formation plus net changes in the level of inventories (Jhingan, 2006).

Capital flight on the other hand is an illegal movement of financial resources from one country to another. It is an abnormal flow of capital, not being sanctioned by the government. This is because exchange of capital controls imposed by the particular country is not adhered to (KindleBerger, 1987). It is also seen as the outflow of capital in the form of massive transfer of currency from one country to another, but Cuddington (1986) in specific terms defines capital flight as short-term speculative outflows by the non-bank private sector. These outflows are caused by short-term flows as well as errors and omissions in the balance of payments accounts. Liquidity shortage that puts pressure on interest rates in the financial sector and scarcity of foreign exchange which may lead to persistent depreciation of domestic currency or loss of reserves are seen as the two basic root causes of capital flight in developing economies. Other causes of capital flight include tax avoidance, foreign debt servicing and trade faking activities. Trade induced capital flight includes the faking of trade documents to circumvent exchange controls in less developed countries. This is because controls most often are characterized by widespread abuses and malpractices such as over-invoicing, forged import licenses or foreign exchange approvals by rent seeking agents and officials (Bhagwati 1964).

Capital flight is different from genuine capital flows in terms of legality. Genuine capital flows out of a domestic economy are recorded on the books of the entity or individual making the transfer, and earnings from the interest, dividends, and realised capital gains normally return to the country of origin to be used to invest and boost economic growth within the domestic economy. On the other hand, all illicit financial flows intended to disappear from any record in the country of origin, and earnings on the stock of illegal capital flight outside of a country that generally do no return to the country of origin are seen as capital flight.

\subsection{Empirical Literature}

The empirical literature on capital flight in Nigeria is rich and diverse. Studies exist on the determinants of capital flight, on the vehicles or mechanisms that fuel the phenomenon, of its impact on economic growth and development, of its effect on poverty and inequality, of its influence on tax revenues, as well as of its effect on external debt. Further investigations have been made on the effect of capital flight on agricultural productivity, and on its impact on the financial system.

Ajayi (1995) for instance, conducted a study on the effects of capital flight on Nigeria's external debt and noted, among several conclusions, of the imprecise and inconclusive nature of the conceptualization of capital flight. The study observed that the specific institutional framework determined considerably the operation of capital flight, and that to curb its menace, a greater role should be ascribed to political and macroeconomic stability. It concluded that capital flight was associated with the availability of foreign exchange which in turn fueled Nigeria's external debt. With rising external debt due to capital flight, it is therefore not surprising that subsequent studies found a negative correlation and impact of capital flight on economic performance (proxied by GDP) generally. With rising foreign debt, resources that would have otherwise been used to finance domestic investment and productivity are rather deployed to defray mounting debts. Thus Umoru (2013), Samson and Edeme (2012), as well as Englama et al. (2007) found evidence of a negative impact of capital flight on economic growth in Nigeria. 
The specific determinants of capital flight have also been of serious concern in many studies. This is so because of the apparent policy implications arising from a deep knowledge of its causative factors. In this regard, Ajayi (1995) documents that financial repression, fiscal deficit, inflation, exchange rate misalignment, as well as trade faking (exports under-invoicing and imports over-invoicing) play significant roles in exacerbating capital flight. This conclusion was earlier established by Nyatepe-coo (1994) who in addition to the above found evidence that the issue of trade faking was rampant in the oil sector, poor governance and corruption. Onwioduokit (2000) later corroborated this position and further documented the role played by parallel exchange rate premium in fueling the crises. Similarly Igwemma, et al. (2018), confirming the deleterious effect of capital flight on the Nigerian economy, further found that looted funds, medical expenses, and foreign education were the fundamental channels through which capital flight was initiated and sustained.

But what is the precise or estimated quantum of capital flight from Nigeria? There are different estimates as there are different measures and approaches. But one thing is abundantly clear: irrespective of the measures used, capital flight in Nigeria is huge, in the billions of dollars, and is a present danger to Nigeria's economic growth. Le and Zak (2006) for instance, estimated the capital flight for Nigeria for 1987 to be 31.0\% of GDP. By 1999, Collier et al (2001) submitted that capital flight from Nigeria stood at $\$ 107$ billion. This is indeed frightening when relating it with 1999 real GDP of $\$ 51.8$ billion, as well as $\$ 78.3$ billion and $\$ 113.1$ billion in 2003 and 2005 respectively. Englama et al. (2007) on their part deployed several measures in estimating capital flight for Nigeria between 1971 and 2006. With the World Bank broad measure of 1985, they found an aggregate capital flight of \$16.14billion for Nigeria; using the Morgan Trust co. measure of 1986, capital flight was estimated to be $\$ 64.26$, and with the Modified Approach, estimated flight capital was $\$ 130.80$. Thus, differences in the estimates go to corroborate previous studies which maintain a lack of consensus on the conceptualization of capital flight. Table 1 and the associated figure 1 show capital flight trend in Nigeria from 1980 to 2017.

Alongside studies which investigate the impact of flight capital on the general economy, its impact on specific sectors has also been explored. Usman and Arene (2014) for instance, examine the effects of capital flight on agricultural sector growth in Nigeria. They found a negative and insignificant effect on the agricultural sector. They conclude that capital flight has no direct effect on the agricultural sector, perhaps its impact is subsumed within other macroeconomic variables. On the other hand, a more narrow implication of capital flight was conducted to determine its impact on tax revenue in Nigeria. Uguru (2016) reveals that a unit increase in capital flight decreases tax revenue by $2 \%$. Similarly, Adetiloye (2012) using the vector error correction mechanism of the ordinary least squares (OLS) regression methodology to analyze data between 1970 and 2007, finds that capital flight has negative but insignificant impact on domestic investment in Nigeria. As noted above, this finding was without basis as the capital flight variable was conspicuously lacking in the model specification, and in the reported results. Similarly, Salandy and Henry (2013), in a study of the impact of capital flight on growth and investment in Trinidad and Tobago found evidence of a negative and significant influence of capital flight on domestic investment.

Cross country panel studies have also been undertaken to ascertain the precise impact of capital flight on domestic investment. One of such studies is Ndiaye (2009), which deploys data from the Central African Economic and Monetary Community (CEMAC) and the West African Economic and Monetary Union (WAEMU). Using the generalized method of moment regression analysis, findings indicate that capital flight negatively affects domestic private investment than public investment, and that the relative magnitude was skewed against CEMAC than WAEMU. Yamesin (2014) similarly employs a dynamic panel methodology for twenty-two emerging market economies between 1975 and 2000 to investigate the effect of capital flight on investment and how it effects changes with financial liberalization policies. The empirical findings indicate that capital flight reduces private investment dramatically but does not have any effect on public investment.

\subsection{Stylized Facts of Capital Flight and Domestic Investment in Nigeria}

The Nigerian economy has witnessed massive outflow of capital (mostly dollar denominated) as politicians, corporate bodies and foreign investors move funds out of the country in response to insecurity, macroeconomic instability as well as exchange and interests rates differentials. Table 1 and the accompanying Figure 1 show the average growth rate of capital flight from Nigeria within intervals of five years beginning from 1980. An alarming picture emerges indicating that between 1980 and 1989, the amount of financial resources fleeing the domestic economy was more than twice (120 percent) its value in the first five years (1980-1984). Two consecutive lull periods spanning a decade was observed between 1990 and 1999. However, the next decade witnessed massive capital outflows which effectively dwarfed the marginal gains recorded in the preceding years. Coincidentally, years of massive capital outflows seem to correlate with years of dwindling growth rates in domestic investment by 
the federal and state governments. Between 1980 and 1989, growth rate of domestic investment witnessed a negative decline exceeding 77 percent. Similar picture emerges between 2015 and 2017.

Thus the combined effects of capital outflows and other macroeconomic uncertainties like expansionary monetary and fiscal policies, coupled with exchange rate misalignments created unconducive domestic environment for investment to thrive. An inflationary macro-environment induced by expansionary policies creates conditions for expected devaluation, making agents to be less confident in government policies aimed to tackle the problem. Consequently agents transfer their assets abroad, leaving domestic capital fragile and incapable of stimulating domestic investment. It must be noted that capital flight responds not only to economic factors of financial repression, differential interest rates, declining terms of trade, exchange rate overvaluations, and fiscal deficits; it also responds to non-economic or social factors of institutional failure manifested in political corruption and lack of accountability (Adesoye, Maku, and Atanda, 2012; Ajayi, 2001).

Table 1. Capital flight data for Nigeria (1980-2017)

\begin{tabular}{|c|c|c|c|c|}
\hline YEAR & $\begin{array}{l}\text { Capital flight } \\
\text { (\$ billion) }\end{array}$ & $\begin{array}{l}\text { Capital flight } \\
\text { growth rate }(\%)\end{array}$ & $\begin{array}{l}\text { Domestic Investment } \\
\text { (\$ billion) }\end{array}$ & $\begin{array}{l}\text { Domestic Inv. } \\
\text { Growth rate }(\%)\end{array}$ \\
\hline $1980-1984$ & 4766.8 & & 69112.5 & \\
\hline 1985-1989 & 10495.1 & 120 & 15481.1 & -77.6 \\
\hline 1990-1994 & 9885.4 & -6 & 16038.7 & 3.6 \\
\hline 1995-1999 & 1252 & -87 & 12824.7 & -20.0 \\
\hline 2000-2004 & 10329.7 & 725 & 23940.2 & 86.7 \\
\hline 2005-2009 & 58292.7 & 464 & 71350 & 198 \\
\hline $2010-2014$ & 44579.3 & -24 & 338052.3 & 373.8 \\
\hline 2015-2017 & 53735.9 & 21 & 214044.87 & -36.7 \\
\hline
\end{tabular}

Source: Author's computation.

Empirically, Adesoye, Maku, and Atanda (2012) investigate the impact of capital flight on investment dynamics in Nigeria, employing time series data from 1970 to 2006. This study established inconsistent results with theory, besides other methodological issues arising from the econometric technique employed in analysis. Specifically the study found capital flight to be an increasing function of domestic investment, much contrary to a priori; it was also an insignificant variable influencing domestic investment in Nigeria. Equally problematic was the instability of the estimated model. The identified gaps in these papers are hopefully corrected in the present effort.

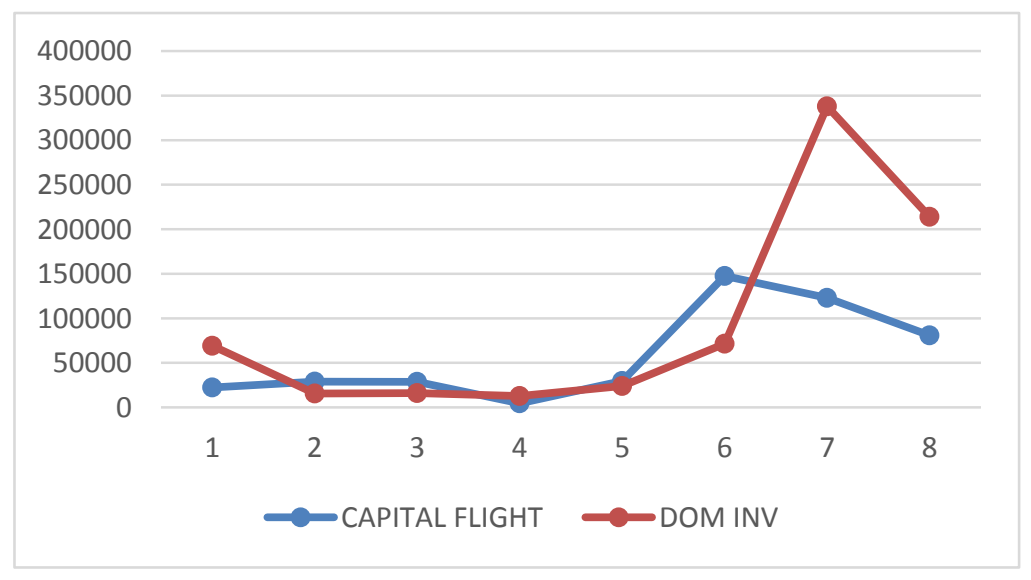

Figure 1. Capital flight and public domestic investment in Nigeria (1980-2017) in billions of US dollars Source: Authors' Computation derived from WDI (2017) 


\subsection{Theoretical Review}

Several theories of capital flight and investment lend themselves to the present study, but a few are briefly reviewed to form part of the theoretical underpinning of the empirical model. First is the investment diversion theory which postulates that because of macroeconomic and political uncertainties in developing countries, coupled with the vent of better investment opportunities elsewhere, agents move their capital, mostly illicitly, abroad first to escape the continuous devaluation of their assets due to such uncertainties, and second to utilize and leverage on better returns to their investments. Better investment environment elsewhere may include political and economic stability, favorable tax climate, attractive foreign interest rates, variety and confluence of financial instruments, as well as secrecy of accounts. With this diversion of financial resources abroad comes the hemorrhaging of domestic investment with its negative ripple effects of slow and negative output growth and high unemployment. Nyong (2015) notes that the poor growth and employment consequent upon persistent capital flight may in turn prompt the need to borrow from outside to rejuvenate the malfunctioning industries and other incapacitated sectors of the economy, thereby perpetuating external dependency and indebtedness. The resulting liquidity constraint due to this diversion may result in domestic currency depreciation, if the economy is operating a floating exchange rate system.

A corollary to the above is the debt-driven capital flight thesis which submits that given the heavy external debt of the country, residents of these countries are motivated to move their resources outside the country to foreign countries. Borrowed funds are sold to domestic economic agents who transfer part of the funds abroad illegally, or the government lends the money to private borrowers through the banking system. The borrower in turn transfers part of the funds abroad. Thus, external debt causes and fuels capital flight (Nyong, 2015). Boyce (1990) and Ajayi (1997) observed that a significant portion of external debt appeared to have been used to finance capital flight as well. Here, capital flees the country as a direct consequence of huge external debt burden.

The portfolio theory of capital flight underlines the fact that external portfolio diversification may be synonymous with capital flight whenever diversified investment does not report returns nor have records at home. Deveruox and Saito (2006) find that the existence of nominal bonds and the portfolio composition of net foreign assets is a significant cause of capital flows between countries. When investors adjust their gross positions in each currency's bonds, countries can achieve an optimally hedged changes in their net foreign assets (or their capital account), thus facilitating international capital flows. Collier et al (2001 and 2004) conclude that the incidence of capital flight anywhere in the world is in response to portfolio choice and risks.

In all, the investment diversion theory approximates the reality of the Nigerian situation. This is because the country is currently plagued by the scourge of insecurity in almost all the regions of the country. There exists the Boko Haram Islamist insurrection in the North East, separatists' uprisings in the South-East, armed banditry in the North West, Fulani herdsmen mayhem in the North-central as well as kidnappings and the sabotaging of Nigeria's oil facilities and resources in the South-south geopolitical zones. The menace of institutional graft, decrepit and inadequate infrastructure add significantly to the burden of capital flight, such that the country has been witnessing a steady decline in investment, both local and foreign, in recent times (Effiom and Edet, 2019; UNCTAD, 2018).

Indeed Cones (1987) demonstrates that investment can be considerably affected by factors such as exchange rate, fiscal and monetary policies. Other determinants of investments include irreversibility and uncertainty, as well as integrity of policy reforms. For instance, investment decision is favourable in conditions of high uncertainty. Thus, when uncertainty is high, agents consequently reduce investment levels. Sources of uncertainty include rising and unpredictable inflation coupled with price volatility, exchange rate volatility, interest rate variability, external shocks to the macro environment, socio-political instability, as well as foreign debt overhang. Gordon and Levin (1989) show that stock of high external debt exert a deleterious effect on investment via the process of credit rationing and debt overhang, the latter viewed as a condition in which heavy debt burden depresses investment simply because potential investors view the stock of accumulated debt as a tax on their income or output in production. Furthermore, Ajayi (2001) and Pastor (1990) find evidence of a positive and significant influence of exchange rate misalignment on capital flight in Nigeria. This implies that exchange rate, working through the capital flight mechanism has negative impact on investment. An overvalued currency will induce agents to shift their domestic currency holdings and wealth to other assets. This is seen as hedge against exchange rate risk in expectation of future devaluation and potential loss. 


\section{Methodology}

\subsection{Model Specification}

The investment diversion theory underpins the empirical model specified below. It states that macroeconomic and governmental uncertainties and presence of wide range of financial instruments abroad, cause economic agents to take away scarce resources from the domestic economy, thereby reducing investible funds and constraining investment within the domestic economy. On this score, the functional form of the model is presented as:

$$
D I N V=f(C A P F, I N T R, R G D P, E X C R, I N F, D B T, I N S T)
$$

The econometric expression of equation (1) assumes the linear form:

$$
\mathrm{DINV}=\lambda_{0}+\lambda_{1} \mathrm{CAPF}+\lambda_{2} \mathrm{INTR}+\lambda_{3} \mathrm{RGDP}+\lambda_{4} \mathrm{EXCR}+\lambda_{5} \mathrm{INF}+\lambda_{6} \mathrm{DBT}+\lambda_{7} \mathrm{INST}+\mu
$$

The semi log-linear specification of equation (2) is expressed as:

$$
\begin{aligned}
\mathrm{LOG}(\mathrm{DINV})= & \lambda_{0}+\lambda_{1} \mathrm{LOG}(\mathrm{CAPF})+\lambda_{2} \mathrm{INTR}+\lambda_{3} \mathrm{LOG}(\mathrm{RGDP})+\lambda_{4} \mathrm{LOG}(\mathrm{EXCR}) \\
& +\lambda_{5} \mathrm{INF}+\lambda_{6} \mathrm{LOG}(\mathrm{DBT})+\lambda_{7} \mathrm{INST}+\mu
\end{aligned}
$$

Where;

DINV = Domestic Investment (sum total of investments by sub-national units and the central government) as a ratio of the GDP

CAPF $=$ Capital Flight to the GDP (residual approach estimated by World Bank 1985)

$\mathrm{EXCR}=$ Real Exchange Rate

INTR $=$ Interest Rate in percentage $(\%)$, captured by domestic lending rate

RGDP $=$ Real Gross Domestic Product

$\mathrm{DBT}=$ Total Debt in billions of naira

$\mathrm{INF}=$ Inflation rate in percentage $(\%)$

INST $=$ Quality of Institutions measured by contract intensive money

$\mu=$ Stochastic error term

$\alpha_{0}=$ Regression Constant or Intercept of the model

$\lambda_{0}-\lambda_{8}=$ Coefficients of economic relationship

Equation 3 says that domestic investment is impacted by capital flight and other relevant macroeconomic variables. From a priori, we expect domestic investment to be a decreasing function of capital flight. Interest rates and inflation mirror the domestic macroeconomic environment and are expected to be negatively related to domestic investment. Domestic investment is also influenced by exchange rate dynamics; a rise in the exchange rate (depreciation of the local currency, the naira) may act as a disincentive for investment because almost all capital goods used in the economy are imported. Its appreciation on the other hand may lead to increases in investment levels. Real gross domestic product, debt, and the quality of institutions should turn out with a positive sign. The quality of institutions in particular moderates the investment environment, as strong institutions enhance investor confidence. Because of the pervasiveness of subjective governance indicators, Clague et al. (1999) develop an objective measure for governance and institutions called Contract Intensive Money (CIM). It measures the enforceability of contracts and security of property rights and is used in this paper.

The ARDL specification of equation (3) is presented as: 


$$
\begin{aligned}
& \Delta D I N V_{t}=c_{0}+\delta_{1} D I N V_{t-1}+\delta_{2} l n C A P F_{t-1}+\delta_{3} I N T R_{t-1}+\delta_{4} \ln R G D P_{t-1}+\delta_{5} \ln E X C R_{t-1}+\delta_{6} I N F_{t-1} \\
& +\delta_{7} \ln D B T+\delta_{8} \operatorname{lnINST}_{t-1}+\sum_{i=0}^{k} \lambda_{1} \Delta D I N V_{t-1}+\sum_{i=0}^{k} \lambda_{2} \Delta \ln C A P F_{t-1}+\sum_{i=0}^{k} \lambda_{3} \Delta I N T R_{t-1} \\
& +\sum_{i=0}^{k} \lambda_{4} \Delta \ln R G D P_{t-1}+\sum_{i=0}^{k} \lambda_{5} \Delta \ln E X C R_{t-1}+\sum_{i=0}^{k} \lambda_{6} \Delta I N F_{t-1}+\sum_{i=0}^{k} \lambda_{7} \Delta D B T_{t-1} \\
& +\sum_{i=0}^{k} \lambda_{8} \Delta I N S T_{t-1}+\mu
\end{aligned}
$$

\subsection{Estimation Techniques and Data Sources}

Data used in the study is secondary time series data from 1980-2017. Data begins from 1980 as some variables lack data from earlier time frames. Domestic investment, interest rates, exchange rates, inflation rates, total debt, and real gross domestic product data were sourced from the Central Bank of Nigeria (CBN) Statistical Bulletin 2018, while data on capital flight was derived from the World Development Indicators. Given the nature of the relationship estimated, and the stationarity properties of the variables in the model, the Auto-Regressive Distributed lag (ARDL) bounds testing approach was employed to estimate the model.

\section{Results and Discussion}

\subsection{Preliminary Tests Results}

A two-pronged approach was adopted to test the general or statistical properties of the data set. First, the descriptive statistics (Table 2) showed that all the variables had low standard deviations that did not radically diverge from their mean values. While the maximum value was 57.16, the minimum was -8.06 . Maximum values were all in excess of their respective mean values, denoting the relevance of the data set in the empirical model. Five of the variables were negatively skewed, denoting a long left tail, while 4 were positively skewed. Inflation and interest rate exhibited leptokurtic kurtosis, with values exceeding the normal distribution of 3 , while others were flat and platykurtic with values of less than 3 .

Second, due to the inherent instability of macroeconomic time series data and the need to avoid spurious regression results arising from their use, the empirical data were analysed to determine their stationarity properties. This was done using the augmented Dickey-Fuller test and the Philips Perron tests. Table 3 presents the results.

Table 2. Descriptive statistics

\begin{tabular}{lllllllll}
\hline $\begin{array}{l}\text { Variabl } \\
\text { es }\end{array}$ & $\begin{array}{l}\text { Observa } \\
\text { tions }\end{array}$ & Mean & $\begin{array}{l}\text { Standard } \\
\text { Deviation }\end{array}$ & $\begin{array}{l}\text { Minimum } \\
\text { Value }\end{array}$ & $\begin{array}{l}\text { Maximum } \\
\text { Value }\end{array}$ & $\begin{array}{l}\text { Skewn } \\
\text { ess }\end{array}$ & $\begin{array}{l}\text { Kur } \\
\text { tosis }\end{array}$ & $\begin{array}{l}\text { Jarque- } \\
\text { Bera }\end{array}$ \\
\hline INF & 38 & 18.79 & 15.87 & 5.38 & 57.16 & 1.55 & 3.98 & 14.15 \\
\hline EXR & 38 & 3.80 & 1.24 & 1.08 & 5.04 & -1.08 & 2.72 & 6.43 \\
\hline INTR & 38 & 12.43 & 5.75 & -8.06 & 26.00 & -0.97 & 6.82 & 24.56 \\
\hline CAPF & 38 & 8.95 & 1.17 & 6.24 & 10.54 & -0.52 & 2.32 & 2.09 \\
\hline DBT & 38 & 6.87 & 2.08 & 2.31 & 9.30 & -0.77 & 2.33 & 3.75 \\
\hline INST & 38 & 0.77 & 0.07 & 0.63 & 0.91 & 0.22 & 1.98 & 1.63 \\
\hline DINV & 38 & 5.59 & 2.56 & 1.75 & 9.39 & 0.04 & 1.57 & 2.72 \\
\hline RGDP & 38 & 10.20 & 0.54 & 9.41 & 11.14 & 0.33 & 1.71 & 2.80 \\
\hline
\end{tabular}

Source: Author's Computation 
Table 3. Unit root test result

\begin{tabular}{lllllll}
\hline ADF & & \multicolumn{5}{l}{ Phillips Perron } \\
\hline Variables & Level & $1^{\text {st }}$ Difference & $\begin{array}{l}\text { Order of } \\
\text { Integration }\end{array}$ & Level & $1^{\text {st }}$ Difference & $\begin{array}{l}\text { Order } \\
\text { Integration }\end{array}$ \\
\hline $\log (\mathrm{CAPF})$ & -2.580119 & -7.632145 & $\mathrm{I}(1)$ & -2.328860 & -7.082355 & $\mathrm{I}(1)$ \\
\hline INF & -3.256979 & - & $\mathrm{I}(0)$ & -2.813714 & - & $\mathrm{I}(0)$ \\
\hline INST & -0.515917 & -4.046740 & $\mathrm{I}(1)$ & -1.162645 & -4.227121 & $\mathrm{I}(1)$ \\
\hline INTR & -4.705264 & - & $\mathrm{I}(0)$ & -4.697018 & - & $\mathrm{I}(0)$ \\
\hline $\log (\mathrm{DBT})$ & -1.654359 & -4.455942 & $\mathrm{I}(1)$ & -1.708856 & -4.406845 & $\mathrm{I}(1)$ \\
\hline $\log (\mathrm{EXCR})$ & -1.820711 & -6.754274 & $\mathrm{I}(1)$ & -1.844544 & -6.683866 & $\mathrm{I}(1)$ \\
\hline DINV & -2.748232 & -4.358330 & $\mathrm{I}(1)$ & -2.812587 & -4.268979 & $\mathrm{I}(1)$ \\
\hline GDP & -2.820907 & -6.749002 & $\mathrm{I}(1)$ & -1.134572 & -6.416684 & $\mathrm{I}(1)$ \\
\hline
\end{tabular}

Test critical values at level: $1 \%=-4.243644,5 \%=-3.544284,10 \%=-3.204699$

Test critical values at $1^{\text {st }}$ difference: $1 \%=-4.252879,5 \%=-3.548490,10 \%=-3.207094$

Source: Author's Compilation

Unit root results indicate that the variables are integrated of different orders, compelling the use of the ARDL bound test methodology in estimating the short and long run co-integrating relationships in the model. Several merits of the ARDL technique compel its use in this instance. It can be used with a hybrid order of integration, usually a combination of $\mathrm{I}(0)$ and $\mathrm{I}(1)$; it can be adaptable to small sample size, and at the same time provides unbiased long run estimates even when they are used with endogenous regressors. Table 4 presents the results of the bounds test of co-integration.

\subsection{Bounds Test for Co-integration}

The result of the ARDL bounds testing approach for the domestic investment model shows that the F-statistic value of 10.360945 calculated at $\mathrm{k}=9$ (number of independent variables) falls above the upper bound critical value at $10 \%, 5 \%, 2.5 \%$ and $1 \%$ significance level. Hence, we conclude that there is a long-run relationship among the model variables.

Table 4. Bounds test co-integration result for the domestic investment model

\begin{tabular}{lll}
\hline Critical Value Bounds & & \\
\hline Significance & $\mathrm{I}(0)$ & $\mathrm{I}(1)$ \\
\hline $\mathbf{1 0 \%}$ & 2.26 & 3.34 \\
\hline $\mathbf{5 \%}$ & 2.55 & 3.68 \\
\hline $\mathbf{2 . 5 \%}$ & 2.82 & 4.02 \\
\hline $\mathbf{1 \%}$ & 3.15 & 4.43 \\
\hline $\mathbf{K}=\mathbf{8}$ & Lag=2 & F-statistic $=10.360945$ \\
\hline
\end{tabular}

Source: Author's computation

\subsection{Results of the Estimated Long Run Domestic Investment Model}

Table 5 presents the long run ARDL results of the domestic investment model. The selected model based on Schwarz Information Criterion (SIC) shows that all the variables are correctly signed and are statistically significant, except institutions which turned out with a negative coefficient. This is not surprising as empirical evidence abound on Nigeria's poor quality of institutions (Udah and Ogbuagu, 2011). Our variable of interest (capital flight) impacts on domestic investment negatively. Specifically, a $10 \%$ increase in capital flight reduces domestic investment by 
5.7\%. Other variables are also shown to impact significantly on domestic investment. For instance a $10 \%$ increase in interest rates reduces domestic investment by $7.31 \%$, consistent with a priori. Similarly, exchange rate, real GDP, inflation, and external debt prove to be significant variables influencing domestic investment in Nigeria. In particular, a one percent increase in external indebtedness, crowds out (reduces) domestic investment by 1.00 percent. Table 6 is the result of the short run error correction model.

Table 5. Estimated long run coefficients for the total domestic investment model

ARDL $(1,0,0,0,0,2,0,0,0)$ Selected Based on Schwarz Information Criterion

Dependent Variable is LOG(DINV)

\begin{tabular}{lllll}
\hline Variable & Coefficient & Std. Error & t-statistic & Probability \\
\hline LOG(CAPF) & -0.573526 & 0.232954 & $-2.461977^{* *}$ & 0.0182 \\
INTR & -0.731832 & 0.221801 & $-3.299498^{*}$ & 0.0023 \\
LOG(RGDP) & 0.734328 & 0.121236 & $6.057009^{*}$ & 0.0000 \\
LOG(EXCR) & -0.194814 & 0.088675 & $-2.196948^{* *}$ & 0.0349 \\
INF & -0.291679 & 0.114979 & $-2.536792^{* *}$ & 0.0159 \\
LOG(DBT) & -1.007985 & 0.068400 & $-14.73657^{*}$ & 0.0000 \\
INST & -0.000194 & 5.58 & $-3.476273^{*}$ & 0.0014 \\
C & 0.198383 & 0.062986 & $3.149635^{*}$ & 0.0040 \\
\hline
\end{tabular}

Source: Author's computation *Significant @ 1\%.**Significant @ 5\%

Table 6. Error correction model for the domestic investment model

ARDL $(1,0,0,0,0,2,0,0,0)$ Selected Based on Schwarz Information Criterion

Dependent Variable is LOG(DINV)

\begin{tabular}{lllll}
\hline Variable & Coefficient & Std. Error & t-statistic & Probability \\
\hline DLOG(CAPF) & -0.271310 & 0.014704 & $-18.45101^{*}$ & 0.0000 \\
D(INTR) & -0.149711 & 0.057224 & $-2.616222^{* *}$ & 0.0126 \\
DLOG(RGDP) & 0.204395 & 0.043793 & $4.667283^{*}$ & 0.0000 \\
DLOG(EXCR) & -0.040362 & 0.102746 & -0.392836 & 0.6967 \\
DLOG(EXCR(-1)) & 0.484346 & 0.057095 & $8.483196^{*}$ & 0.0000 \\
D(INF) & -0.000384 & 0.000155 & $-2.472394^{* *}$ & 0.0187 \\
DLOG(DBT) & 0.414770 & 0.105976 & $3.913796^{*}$ & 0.0004 \\
D(INST) & -0.001860 & 0.000858 & $-2.168099^{* *}$ & 0.0372 \\
ECM(t-1) & -0.798063 & 0.200718 & $-3.976048^{*}$ & 0.0004 \\
\hline
\end{tabular}

R-squared: 0.845324; Adjusted R-squared: 0.827654

F-statistic: 637.3215; Durbin-Watson: 1.999782

Prob(F-statistic): 0.000000

Source: Author’s computation. *Significant @ 1\%.**Significant @ 5\%

The error correction model captures the short-run dynamics of the system and its coefficients, and the error correction term measures the speed of adjustment from the short-run disequilibrium to the long-run equilibrium in the event of shocks. The results show a high and significant speed of adjustment of $79.8 \%$. The estimated short-run coefficients are generally consistent with the earlier reported long run results in terms of a priori expectations and 
are statistically significant. In the short run, domestic investment responds negatively to capital flight. Exchange rate was however not statistically significant in the short run.

The diagnostic properties of the model indicate that the model is stable and well behaved. Specifically, the D-W statistic of 1.999782 indicates that there is no serial correlation in the residuals. The overall regression is significant at one percent as can be seen from the Adjusted R-squared and the F-statistic. The Adjusted R-squared value of 0.827654 indicates that about 82 percent of the change in domestic investment is explained by changes in the independent variables. Also, the F-statistic value of 637.3215 suggests the joint significance of the determinants in the error correction model.

The conventional test for serial auto-correlation is the Durbin-Watson (DW) statistic. But in the case of an auto-regressive model, the DW statistic is inadequate in determining whether there is serial correlation in a regression model. Hence, the alternative serial correlation test for an auto-regressive model is the Q-statistic test or the LM test for serial correlation. The Q-statistic test for serial correlation is employed in this study since the models are autoregressive.

The null hypothesis states that there is no serial correlation in the total domestic investment model, while the alternative hypothesis states that there is serial correlation in the total domestic investment model. From the probability values which are all greater than five percent (Table 7), the null hypothesis is accepted. Hence, there is no serial correlation in the total domestic investment model.

Table 7. Q-statistic test for serial correlation in the total domestic investment model

\begin{tabular}{llll}
\hline Autocorrelation & Partial Correlation & Q-stat & Probability \\
\hline-0.510 & -0.510 & 0.8354 & 0.455 \\
\hline 0.211 & -0.066 & 0.2329 & 0.310 \\
\hline-0.333 & -0.342 & 1.0854 & 0.785 \\
\hline 0.084 & -0.348 & 1.2093 & 0.411 \\
\hline-0.025 & -0.253 & 0.0115 & 0.622 \\
\hline 0.076 & -0.243 & 0.3330 & 0.938 \\
\hline 0.084 & -0.089 & 2.6102 & 0.459 \\
\hline-0.212 & -0.392 & 0.1469 & 0.551 \\
\hline 0.274 & -0.066 & 2.7030 & 0.328 \\
\hline-0.242 & -0.132 & 0.4017 & 0.418 \\
\hline
\end{tabular}

Source: Author's computation.

\section{Conclusion and Recommendations}

Capital flight in developing countries, including Nigeria, is exacerbating in spite of the public outcry against it. The publishing of the Panama papers is evidence of the monumental scale of capital flight in developing countries. Nigeria is caught in the fray as billions of dollars are laundered out of the country through all kinds of illicit procedures. While the effect of capital flight on economic growth, income inequality and poverty has gained enormous space in the literature, its impact on domestic investment, which is a precursor to economic growth, has however not received the needed attention. This paper therefore empirically investigated the capital flight effects of domestic investment in Nigeria.

The paper finds that capital flight compromises domestic investment both in the short -run and long-run. Its long run impact on domestic investment (0.57) turns out to be more severe than the short run (0.27), implying that a continuous and persistent build-up of capital flight exerts a negative cumulative effect on domestic investment over time. Our findings are consistent with theory and extant macroeconomic reality in Nigeria. It is however at variance with Adesoye, Maku, and Atanda (2012) who found a positive and insignificant relationship between capital flight and investment. That study effectively said that increases in capital flight increases investment levels in Nigeria. Reality shows this to be incorrect. Our findings correct the Adetiloye (2012) study which omitted the capital flight 
variable in the estimated domestic investment equation. The study further reveals that the quality of institutions in Nigeria is a disincentive to domestic investments. This findings aligns with Ndikumana (2000) who averred that weak institutions in developing countries was a leading causative factor of capital flight, which further weakened investment capacity of the domestic economy. The estimated coefficients of exchange rate, inflation, interest rates, and foreign debt confirmed the investment diversion theory.

On the basis of these findings, the study recommends that government efforts should be directed at curbing the illegal outflow of capital in order to ensure that investible funds are available within the domestic economy for the purpose of investment. This calls for the building and strengthening of institutions, which in the result was found to be a significant variable influencing domestic investment in Nigeria. Since foreign debt impacts negatively on domestic investment, a credible and workable external debt threshold should be established to curb Nigeria's rising debt profile. This would reduce the debt burden and make funds available for domestic investment.

\section{References}

Adesoye, A. B., Maku, A. E., \& Atanda, A. A. (2012). Capital Flight and Investment Dynamics in Nigeria: A Time Series Analysis (1970-2006). MPRA Paper No. 35836. Retrieved from https://mpra.ub.uni-muenchen.de/35836/

Adetiloye, K. A. (2012, February). Capital flight versus domestic investment in developing countries: An empirical analysis from Nigeria. International Journal of Economics and Finance, 4(2). https://doi.org/10.5539/ijef.v4n2p175

Ajayi, S. I. (1997). Capital flight and external debt in Nigeria. Research Paper No. 35, African Economic Research Consortium.

Ajayi, S. I. (1997). External debt and capital flight in sub-saharan Africa. IMF Publication.

Ajayi, S. 1. (2001). An Economic Analysis of Capital Flight from Nigeria. World Bank P.R.P Paper No. 993.

Bhagwati, J. (1964). On the underinvoicing of imports. Oxford Bulletin of Economics and Statistics, 27(4), 389-397. https://doi.org/10.1111/j.1468-0084.1964.mp27004007.x

Boyce, J. K. (1990). The revolving door? External debt and capital flight: A Philippine case study. World Development Journal, 20(3), 335-349. https://doi.org/10.1016/0305-750X(92)90028-T

CBN Statistical Bulletin. (2017). from http://www.cenbank.org/OUT/PUBLICATIONS/STATBULLETIN/RD/2010/STABULL-2017.PDF

Clague, C., Keefer, P., \& Knack, S. (1999). Contract-intensive money: contract enforcement, property rights and economic performance. Journal of Economic Growth, 4(2), 185-211. https://doi.org/10.1023/A:1009854405184

Collier, P., Hoeffler, A., \& Pattillo, C. (2004). Aid and capital flight. Oxford University: Centre for the Study of African Economies.

Collier, P., Hoeffler, A., \& Pattilo, C. (2001). Flight capital as a portfolio choice. The World Bank Economic Review, 15(1), 15e80. https://doi.org/10.1093/wber/15.1.55

Cones, E. R. (1987). The Causes of capital flight from Latin America. Inter-America Development Bank Washington.

Cuddington, J. T. (1986). Capital flight, issues and explanations. Princeton Studies in International Finance (p.58). Princeton, NJ: Princeton University.

Deppler, M., \& Williamson, M. (1987). Capital flight: Concepts, measurement and issues. Staff Papers for the World Economic Outlook. International Monetary Fund, Washington, DC.

Devereux, M. B., \& Saito, M. (2006). A portfolio theory on international capital flows. IIIS Discussion Paper No. 124. https://doi.org/10.2139/ssrn.922305

Effiom, L., \& Ebi, B. O. (2016). Foreign direct investment in Cross River State, Nigeria: An evaluation of investment policy framework. Nigerian Journal of Economic and Social Studies, 58(3).

Effiom, L., \& Edet, S. E. (2019). Facilitation of foreign direct investment: Evidence from Cross River State, Nigeria. International Journal of Accounting \& Finance, 8(2). 
Englama, A., Oputa, N. C., Ogunleye, T. S., \& Omotosho, B. S. (2007). Capital flight from Nigeria: An empirical estimate. Central Bank of Nigeria Economic and Financial Review, 45(3).

Financial Times. (2014). The FDI Report.

Gordon, G. B., \& Levin, R. (1989). The problem of capital flight - a cautionary note. World Economy, 12. https://doi.org/10.1111/j.1467-9701.1989.tb00732.x

Heim, J. J. (2008). The investment function: Determinants of demand for investment goods. Rensselaer Working Papers in Economics.

Igwemma, A. A., Egbulonu, K. G., \& Assumpta, C. N. (2018). Capital flight and the Nigerian economy (1986-2016). International Journal of Development and Economic Sustainability, 6(4), 11-28.

Jhingan, M. L. (2006). Principles of Economics (2nd ed.). Vrinda Publications (p) Ltd.

Kindleberger, C. P. (1987). A historical perspective. In Lessard, D. R. \& Williamson, J. (Eds.), Capital flight and third world debt. Washington DC Institute for International Economics.

Lawanson, A. O. (2008). An econometric analysis of capital flight from Nigeria: A portfolio approach. Africa Economic Research Consortium paper No. 166.

Le, \& Zak. (2006). Corruption and capital flight: an empirical assessment. International Economic Journal, 20(1), 532-540. https://doi.org/10.1080/10168730601027161

Ndiaye, A. S. (2009, July 8-10). Effect of capital flight on domestic investment in the franc zone. African Econometric Society. $14^{\text {th }}$ Annual Conference on Econometric Modeling for Africa, Sheraton hotel, Abuja, Nigeria.

Ndikumana, L. (2000). Financial development, financial structure, and domestic investment: International evidence. Working Paper Series, No. 16, Political Economy Research Institute, University of Massachusetts Amherst.

Ndikumana, L., \& Boyce, J. K. (2018). Capital flight from Africa: Updated methodology and new estimates. Political Economy Research Institute (PERI) Report. University of Massachusetts-Amherst.

Nyatepe-Coo, A. A. (1994). Capital flight in low-income sub-Saharan Africa. The effects of political climate and macroeconomic policies. Scandinavian Journal of Development Alternatives, 59-68.

Nyong, M. O. (2015). International Economics; Theory, Policy and Application (3rd ed.). Wusen Publishers.

Onwioduokit, E. A. (2000). Capital flight from Nigeria: an empirical examination. West African Monetary Institute, Accra, Ghana.

Pastor, M. (1990). Capital Flight from Latin America. https://doi.org/10.1016/0305-750X(90)90099-J

Salandy, M., \& Henry, L. (2013). The impact of capital flight on investment and growth in Trinidad and Tobago, 1971-2008. Retrieved from https://pdfs.semanticscholar.org

Samson, O., \& Edeme, R. (2012). Capital flight and Nigeria's economy. JORIND, 10(2).

Udah, E. B., \& Ogbuagu, R. (2011). Constraints to economic development and growth in Nigeria. European Journal of Scientific Research, 65, 581-593.

Uguru, L. C. (2016). On The Tax Implications of Capital Flight: Evidence from Nigeria.

Umoru, D. (2013). Capital flight and the Nigerian economy. European Journal of Business and Management, 5(4).

United Nations Conference on Trade and Development (UNCTAD). (2018). World Investment Report. Retrieved from http://unctad.org/wir or http://unctad.org/fdistatistics

Usman, F. R., \& Arene, C. J. (2014). Effects of capital flight and its macroeconomic determinants on agricultural growth in Nigeria. International Journal of Food and Agricultural Economics (IJFAEC), 2(4), 107-126.

World Bank. (1985). World development report 1985. Washington, D.C.: World Bank. https://doi.org/10.1596/0-1952-0482-4

World Bank. (2007). World development report 1985. Washington, D.C.: World Bank.

World Bank. (2015). World development indicators 2015. Washington, D.C.: World Bank.

Yalta, A. Y. (2014). Effect of capital flight on investment: Evidence from emerging markets. Emerging Markets Finance and Trade Journal, 46(6), 40-54. https://doi.org/10.2753/REE1540-496X460603 